\title{
SELECTED PROBLEMS PERTAINING TO MODERNISATION OF LAND AND BUILDING RECORDS - DETERMINATION OF BOUNDARIES OF REAL ESTATE PLOTS
}

\author{
Szczepan Budkowski, Jacek Gniadek
}

\begin{abstract}
Summary
In Poland, the land and building records (EGiB) function as real estate cadastre, and are subject to periodic and on-going updating in accordance with applicable regulations. In addition to upgrades aimed at bringing the field status in line with the registration status, land and building records' modernizations are also being carried out. The purpose of modernization is to improve the quality of collected data as well as their standardization and harmonization. Modernization works can be carried out through field measurements or the use of photogrammetric technology. The purpose of this publication is to clarify the problems associated with determining the boundaries of registration plots in the context of modernization works performed using the photogrammetric method. The paper includes an assessment of technical and legal aspects related to the above-mentioned tasks.
\end{abstract}

\section{Keywords}

EGiB modernization • real estate cadastre $\bullet$ data reliability

\section{Introduction}

The Polish Geodesy and Cartographic Act of 1989 [Prawo Geodezyjne i Kartograficzne - Act 1989] contained a designation to the regulation, which implemented the imposed obligation to define the rules for establishing and keeping records of land and buildings throughout the country. The Regulation of 1996 [Regulation 1996] was the first to tackle the task of digitizing the geodetic and cartographic resources. The regulations set out the objectives and stages of modernization, which was aimed at achieving the harmonization of the information scope, and digitization of the resources. Under Regulation 1996 [Regulation 1996], work was undertaken to create a numerical cadastral map. The next regulation, issued in 2001 [Regulation 2001], defined the modernization of the land and building records as a set of actions taken to harmonize the existing data and acquire new data in digital format. The only method of obtaining data that guaranteed specific accuracy was field measurement. In $\$ 82$ paragraph 1 , the 
regulation also allowed the use of existing data, provided that accuracy of not less than $3.0 \mathrm{~m}$ in rural areas was obtained, and $0.60 \mathrm{~m}$ in urban districts, relative to the detailed third-order geodetic network. The amendment to the regulation in 2014 [Regulation 2001] introduced changes to the rules for modernizing the land and building records, as the division into continuous and comprehensive modernization was abandoned. A provision has also been removed that had previously allowed keeping the data on area of the plot of land from the former records in the current ones, even if the location of boundary points had been determined on the basis of the data that did not meet the specified accuracy.

After 2014, subsequent amendments to the regulation on land and building records [Regulation 2001] allow the possibility of performing modernization works not only by means of direct measurements, but also by using the photogrammetric method if there is a lack of geodetic documentation meeting the accuracy requirements of applicable technical standards.

The problems of low data quality, especially in the area of the former Austrian partition, are dealt with by Mika, Siejka [Siejka et al. 2016]. The results of research by Adamczyk and Jasiołek [2012] indicate that the correct use of the existing cadastral records can bring measurable effects and produce important documentation in the process of establishing boundaries and regulating legal status.

The assessment of the use of photogrammetry in a purely technical aspect is raised by Gajderowicz and Żarnowski [2002], who analyse the resolution of the aerial photographs used. Also the works by Kurczyński and Bakuła [2016], who analyse the use of aerial photographs in the process of setting borders, are valuable studies from the scientific point of view. The topics pertaining to the modernization of records appear not only in individual studies, but also in collective works [Akińcza et al. 2015].

\section{Research problem and methodology}

In the present study, the data from the area of Ostrowiec district were analysed, where modernization works related to the Integrated Real Estate Information System were conducted in 2017-2018. The works were carried out using a photogrammetric method, whereas the technical conditions [OPZ 2016] attached to the project obliged the contractor to conduct field measurements in places where the materials obtained from the documentation centre were of insufficient reliability. The analysis of the land and building records data was supported by the verification of administrative-legal and technical procedures.

Hence, the overriding issue seems to be the basis for the decision to carry out the modernization using the photogrammetric technology, which according to $\$ 37$ section 1 of the Regulation on land and building records [Regulation 2001] would be the lack of geodetic documentation, or low reliability of the existing data. It should therefore be noted that the provisions of the Regulation refer to the term "data reliability" without actually defining it. In the content of the regulation, the term is also not associated with 
the attribute of point location error, which might cause ambiguity in determining the technical conditions for the modernization works that are carried out. In the modernization works described herein, the terrain pixel is 7 centimetres, thus the resolution of aerial photographs is at a satisfactory level (Fig. 1).

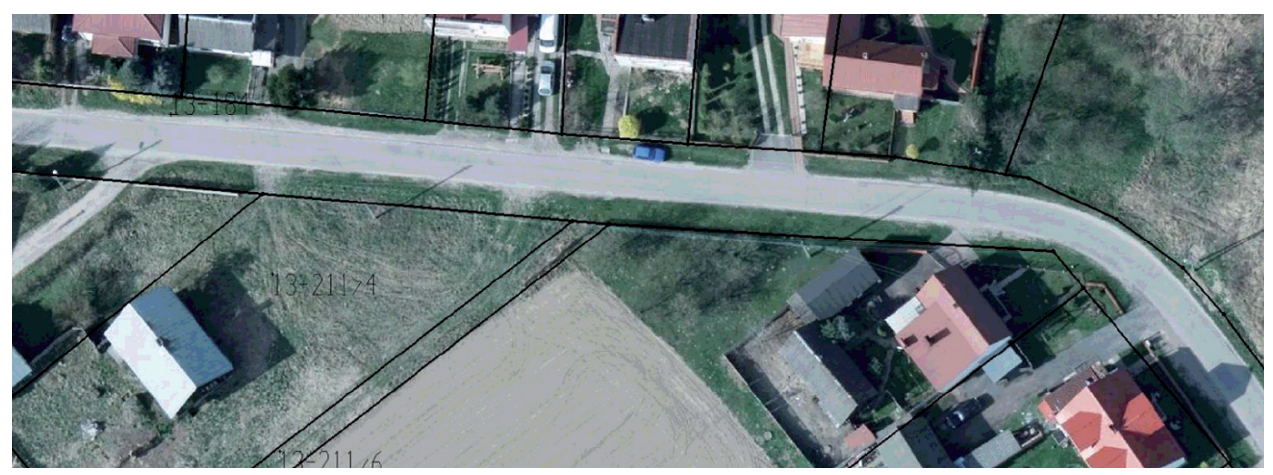

Source: Authors' own materials

Fig. 1. Orthophotomap with marked boundaries of registration plots

In order to clarify $\$ 37$ section 1 of the Regulation on land and building records [Regulation 2001], the author of the article proposes to extend the above-mentioned paragraph by including the following provision: "\$37 section 1a: The documents collected in the PZGiK should be considered unreliable, if the analysis by the contractor of works, as part of the act specified in $\$ 6$ of the Regulation on technical standards, shows that:

1) they were prepared on the basis of measurements taken inaccurately or with insufficient accuracy, which cannot be improved as a result of harmonizing the existing border coordinates by mathematical transformation or as a result of recalculation of the geodetic matrix and boundary points,

2) they are contradictory to other documents specifying the course of boundary, in particular those disclosed in the land and mortgage records or stored in State archives or private archives,

3) the measurement of boundary points was made in the local coordinate system and it is not possible to perform the conversion to the applicable national spatial reference system".

Regulation of the land and building records [Regulation 2001] in $\$ 39$ defines the criteria for determining the registration boundaries of plots, as the first to include the provision of consistent indications (concordant statements) by the owners or holders of perpetual usufruct of those plots or persons with the title of spontaneous possession, confirmed by their consistent declaration submitted to the protocol. The second way of 
determining the plot boundary is possible if the course of the boundaries of registration plots, including the location of the border points thereof, is determined by the contractor according to the status of last quiet enjoyment. Another way of determining the boundaries is applied in the cases where it is impossible to establish the last quiet enjoyment status or if the latter is contrary to the information contained in the available documents determining the legal status of land within these plots. The criteria for determining the boundaries of the plot are presented in Figure 2.

Criteria for establishing

the boundaries of cadastral plots

$\S 39$ of the EGIB regulation

1. Determining the course of the boundaries of cadastral plots, including the locations of boundary points that define them, is done by the contractor

based on concordant statements

by the owners or holders of perpetual usufruct of those plots or persons of spontaneous possession,

confirmed by their consistent declaration

submitted to the protocol of determining the registration boundaries of plots

2. In the case where the relevant parties do not submit a consistent declaration to the protocol of determining the registration boundaries of plots,

the course of the boundaries of cadastral plots, including the locations of boundary points that define them, is determined by the contractor according to the status of last quiet enjoyment, provided that this status is not contrary

to the information contained in the available documents determining the legal status of the land within these plots' boundaries

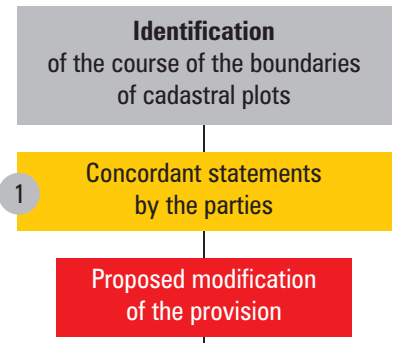

[...] provided that this status is not contrary to the information

contained in the available documents determining the legal status of the land within these plots' boundaries

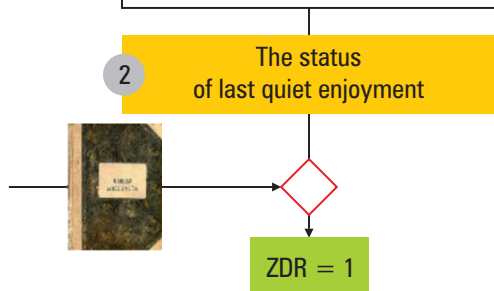

Source: Felcenloben [2018]

Fig. 2. Criteria for the determination of the course of boundaries

The determination of the boundaries of cadastral plots, carried out as part of the modernization of the land and building records, also applies to the determination of the boundary lines (banks) of natural watercourses. This is an extremely important issue considering the fact that we are dealing with modernization with the use of photogrammetric technology.

It is an unquestionable advantage of modernization conducted using this method that it facilitates saving time and money, especially in the case of large-scale studies. The photogrammetric method guarantees the homogeneity of the result, facilitates better control, and also generates fewer errors. The material obtained in the form of 
high-resolution photos makes it possible to unambiguously identify details in the field, which are often a guide to establishing the boundaries of cadastral plots, or they constitute points of reference in the determination procedure.

\section{Results}

Nevertheless, the use of the photogrammetric method to determine plot boundaries requires careful analysis of the available source data. This is due to the fact that the orthophotomap thus developed presents only the land use, which may differ from the existing documentation and legal status. Real estate with a typically agricultural or forestry use is particularly vulnerable to the informal transfer of ownership. Plot boundaries are not clearly identifiable in this case by terrain details, whereas the border points marking the course of the boundary often get damaged, destroyed, or shifted. The accompanying figure shows the situation visible on the orthophotomap, along with the analysis of available documentation obtained from the centre. The author of the article shares the view of D. Felcenloben [Felcenloben 2018] about the need to modify $\$ 39$ section 1, and supplementing it with a provision ensuring the verification of source materials prior to the determination of the parties' consistent statement (Fig. 3).

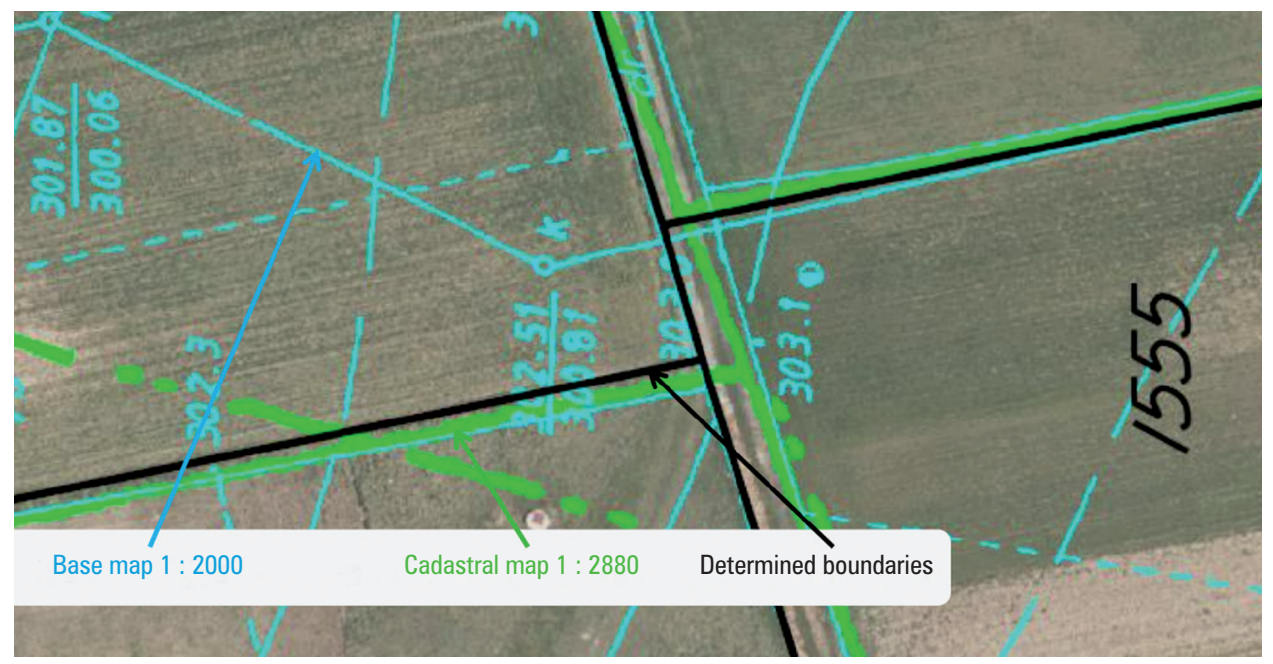

Source: Authors' own materials

Fig. 3. The completed analysis of source materials against the background of the orthophotomap

Another example in which determining boundaries by the photogrammetric method can be burdensome is determining the boundary lines of watercourses (Fig. 4). In the attached example, the proposed course of the watercourse's boundary line was drawn from the stereoscopic model, shown as the red line. The black lines show the 
boundaries of cadastral plots. As can be seen, the precise determination of the boundary lines (banks) is hampered by the existence of significant trees near the river. An additional difficulty in this case is the inconsistency of regulations. The Regulation on the land and building records [Regulation 2001] states in \$82a that "Until the boundary line of natural watercourses, lakes and other natural water reservoirs is established according to the principles set out in the provisions of Article 15 and Article 15a of the Act of July 18, 2000 - Water Law, the boundaries of registration plots between the lands forming the bottoms and banks of these watercourses, lakes, and reservoirs, and the land adjacent to them are shown in the records using data determined on the basis of the results of geodetic surveys of situational measurements, when the identification of the border was made in accordance with the provisions of Art. 15 sections 1.5 and 6 of the Act of 18 July 2001 i.e. Water Law."

The above provision refers to the Water Law that is no longer valid [Act 2001], and furthermore it does not specify the procedure by which the above-mentioned determination could be considered appropriate. Also, the provision does not contain any information regarding the type and content of documentation that should be drafted.

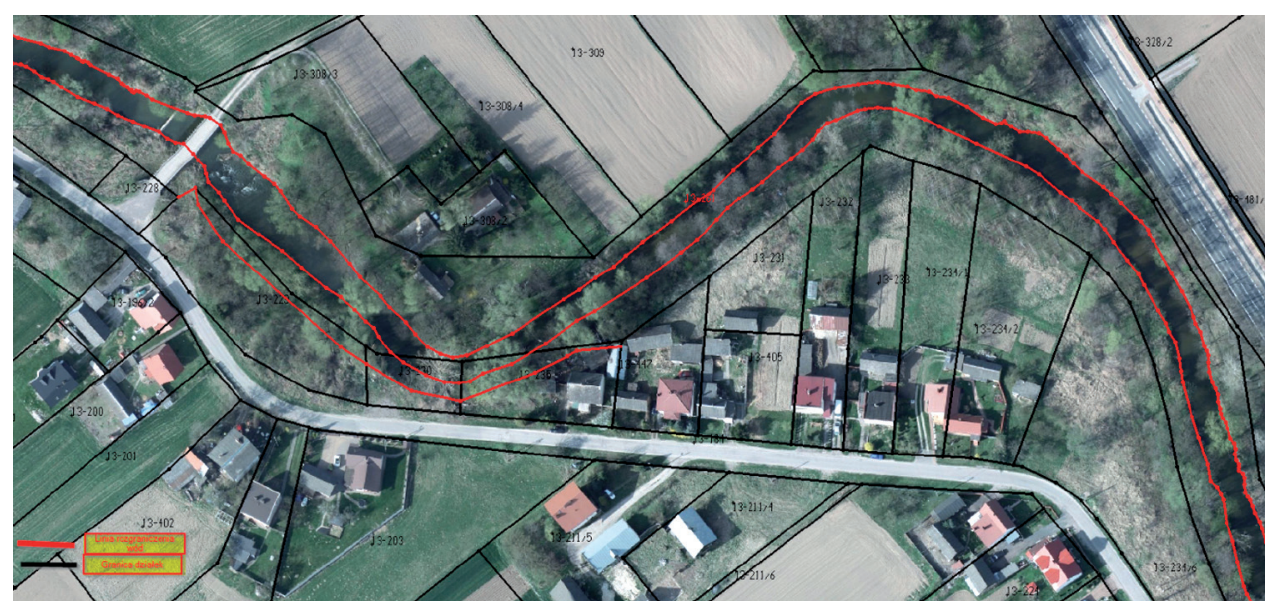

Source: Authors' own materials

Fig. 4. A sample boundary line of a watercourse

Determining the boundary line of the watercourse after January 1, 2018 should take place in accordance with article 220 of the Act of 20 July 2017 Water Law [Act 2017]. However, these provisions do not contain any reference to the modernization procedure under which they are in fact used. A correctly completed procedure for determining the boundary line of a watercourse should look like this (Fig. 5): 


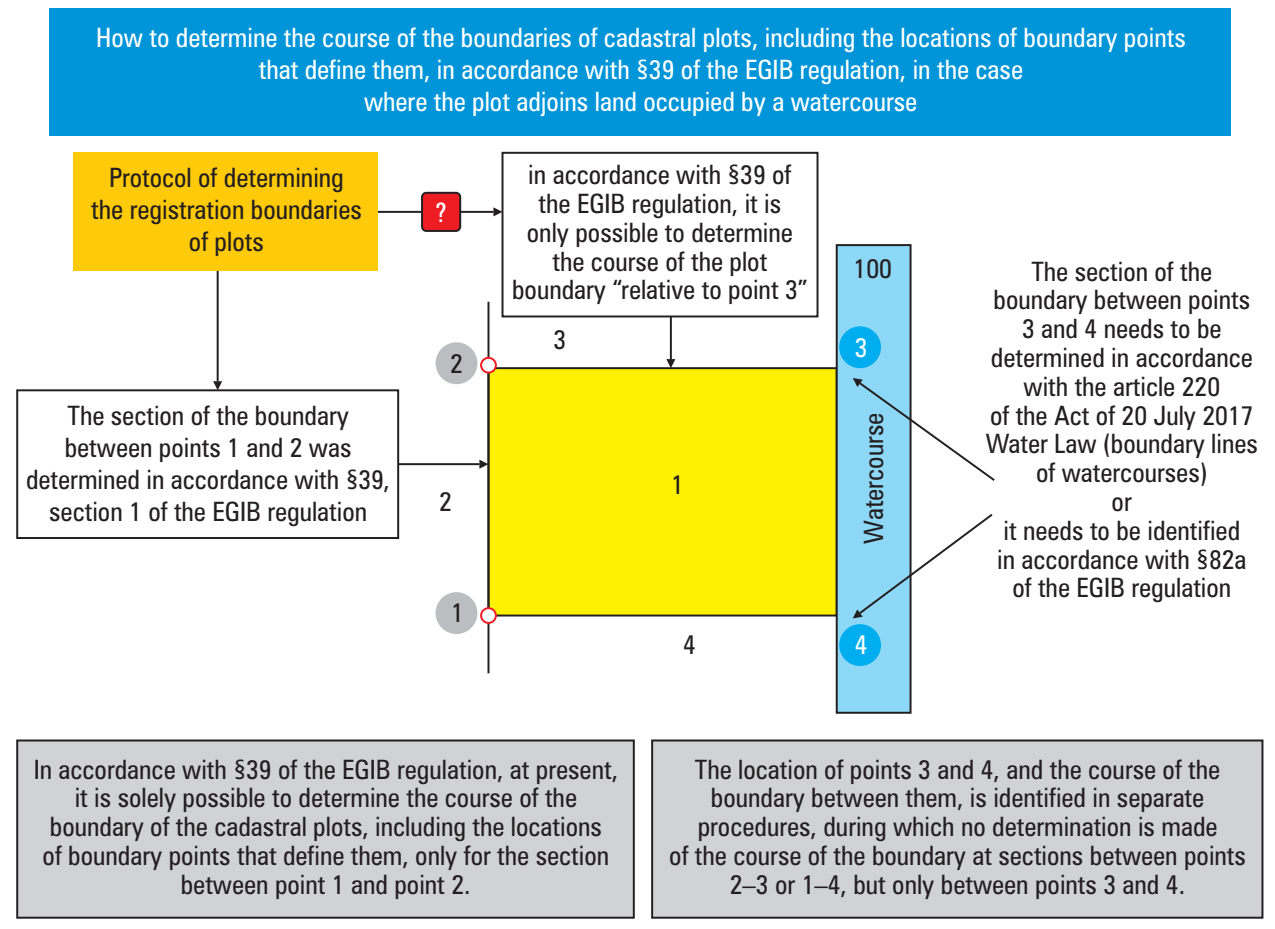

Source: Felcenloben [2018]

Fig. 5. Procedure for determining plot boundaries and determination of the boundary lines of watercourses

\section{Conclusions}

The results of the analysis of legal provisions demonstrated their inconsistency and mutual lack of compliance. An imprecise definition of the modernization procedure, coupled with inaccurate documentation analysis, can in some cases legitimize informal land trading. In this author's opinion, special attention should also be paid to the change of legislation regarding the determination of the watercourse boundary lines, that is, updating of regulations, as well as the inclusion of the procedure for determining the boundary lines of watercourses into the regulation.

The above conclusions do not undermine the legitimacy of conducting modernization using the photogrammetric method, but they only indicate areas of operations that require special diligence from the contractors of works, as well as refinement in the legislative field. Modernization with the aid of photogrammetric measurements is a much more economical solution in terms of both financial outlays and time. The studies thus prepared guarantee uniformity, and the collected data in the form of orthophotomaps document the field details that help determine the course of the boundaries. 
The study conducted using this method is comprehensive, and it facilitates the analysis of areas that might not be available if classic measurement method was used.

\title{
References
}

Act 1989. Ustawa z dnia 17 maja 1989 r. - Prawo geodezyjne i kartograficzne (Dz. U. z 1989 r. Nr 30, poz. 163).

Act 2001. Ustawa z dnia 18 lipca 2001 r. - Prawo wodne (Dz. U. z 2001 r. Nr 115, poz. 1229).

Act 2017. Ustawa z dnia 20 lipca 2017 r. - Prawo wodne (Dz. U. z 2017 r., poz. 1566).

Adamczyk T., Jasiołek J. 2012. Analiza dokumentacji katastru gruntowego dla byłej gminy Hrebenne. Infrastruktura i Ekologia Terenów Wiejskich, 1(3), 19-30.

Akińcza M., Bieda A., Buśko M., Hannibal H., Hanus P., Hycner R., Krzyżek R., Kwartnik-Pruc A., Łuczyński R., Przewięźlikowska A. 2015. Aktualne problemy katastru w Polsce. Oficyna Wydawnicza Politechniki Warszawskiej, Warszawa.

Felcenloben D. 2018. XXI Kaliska Konferencja Naukowo-Techniczna, 18-20.09.2018.

Gajderowicz I., Żarnowski A. 2002. Modernizacja ewidencji gruntów i założenia ewidencji budynków na podstawie metod i technologii fotogrametrii cyfrowej. Archiwum Fotogrametrii, Kartografii i Teledetekcji, 12.

Kurczyński Z., Bakuła K. 2016. Ocena możliwości współczesnej fotogrametrii w pracach z zakresu ewidencji gruntów i budynków. Przegląd Geodezyjny, 7, DOI:10.15199/50.2016.7.1.

Regulation 1996. Rozporządzenie Ministrów Gospodarki Przestrzennej i Budownictwa oraz Rolnictwa i Gospodarki Żywnościowej z dnia 17 grudnia 1996 r. w sprawie ewidencji gruntów i budynków (Dz. U. z 1996 r. Nr 158, poz. 813).

Regulation 2001. Rozporządzenie Ministra Rozwoju Regionalnego i Budownictwa z dnia 29 marca 2001 r. w sprawie ewidencji gruntów i budynków (Dz. U. z 2001 r. Nr 38, poz. 454).

Siejka M., Ślusarski M., Mika M., Leń P. 2016. Modernizacja ewidencji gruntów i budynków w świetle obowiązujących przepisów prawnych. Infrastruktura i Ekologia Terenów Wiejskich, II(1), PAN, Kraków.

OPZ 2016. Opis przedmiotu zamówienia, 2016, powiat ostrowiecki, GK-I.033.7.2016.

\author{
Mgr inż. Szczepan Budkowski \\ GEO-Mapa Szczepan Budkowski \\ 37-450 Stalowa Wola, ul. Staszica 15b/19 \\ e-mail: szbudkowski@o2.pl \\ Dr inż. Jacek Gniadek \\ Uniwersytet Rolniczy w Krakowie \\ Katedra Geodezji Rolnej, Katastru i Fotogrametrii \\ 30-198 Kraków, ul. Balicka 253a \\ e-mail: Jacek.gniadek@urk.edu.pl \\ ORCID: 0000-003-4381-5018
}

